\title{
More new records of spider wasps from Colombia (Hymenoptera, Pompilidae)
}

\author{
Cecilia Waichert', Fernando Fernández², Valentina Castro-Huertas ${ }^{2,3}$, \\ Juanita Rodriguez ${ }^{4.5}$, James P. Pitts ${ }^{6}$
}

I Universidade Federal do Espirito Santo, Departamento de Ciências Biológicas, Vitória, ES, Brasil 2 Instituto de Ciencias Naturales, Universidad Nacional de Colombia, Bogotá D.C., Colombia 3 Laboratório de Entomologia Sistemática, Instituto de Biociências, Universidade Federal do Rio Grande do Sul, Porto Alegre, RS, Brasil 4 Australian National Insect Collection, CSIRO, Canberra, ACT, Australia 5 Department of Biological Sciences, Auburn University, Auburn, AL, USA 6 Department of Biology, Utah State University, Logan, UT, USA

Corresponding author: Cecilia Waichert (cwaichert@gmail.com)

Academic editor: M. Engel | Received 17 September 2016 | Accepted 20 December 2016 | Published 23 February 2017

http://zoobank.org/10EDA22D-9BB5-49CA-8A79-09B1BD7BFB65

Citation: Waichert C, Fernández F, Castro-Huertas V, Rodriguez J, Pitts JP (2017) More new records of spider wasps from Colombia (Hymenoptera, Pompilidae). ZooKeys 658: 89-95. https://doi.org/10.3897/zookeys.658.10538

\begin{abstract}
Aporinellus Banks, Austrochares Banks and Dicranoplius Haupt are new generic records for Colombia, as well as the species Dipogon ariel Banks, Evagetes peruana Banks, and Euplaniceps notabilis (Smith). Five new combinations are formally endorsed: Aimatocare argentinica (Banks), comb. n.; Aimatocare longula (Banks), comb. n.; Aimatocare imitator (Evans), comb. n.; Aimatocare impensa (Evans), comb. n.; Aimatocare vitrea (Fox), comb. n. Although these names have been used in Pompilidae, no formal nomenclatural act had been proposed. The presence of Chirodamus paramicola Roig-Alsina, previously reported with uncertainty, is confirmed. Finally, a new combination for Euplaniceps notabilis (Smith), comb. n. is proposed based on molecular phylogenetics and morphological data. The Colombian fauna of Pompilidae sums up to 38 genera and approximately 150 species.
\end{abstract}

\section{Keywords}

New combination, Pepsinae, Pompilinae

Copyright Cecilia Waichert et al. This is an open access article distributed under the terms of the Creative Commons Attribution License (CC BY 4.0), which permits unrestricted use, distribution, and reproduction in any medium, provided the original author and source are credited. 


\section{Introduction}

The mostly solitary spider wasps (Hymenoptera: Pompilidae) are a widespread group of more than 1,000 species in four subfamilies and 60 genera in the Neotropics (Fernández 2000, Hanson and Wasbauer 2006). Despite some recent progress in the taxonomic study of Neotropical pompilids (e.g. Rodriguez et al. 2010, Waichert et al. 2012, Waichert et al. 2015), their nomenclature and systematics remains incipient. As a result, several genera lack identification keys and urge taxonomic revision, and many species remain to be described.

With the growing anthropogenic pressures on the Neotropical forests, one of the main concerns is the loss of biodiversity, which increases the need of prioritizing taxonomic studies in these areas. The authors are currently engaged in the monograph of spider wasps from Colombia, including keys to subfamilies, tribes, genera and species of several genera. This endeavor favored the publication of new genera and species records (Castro-Huertas et al. 2014). Because we are approaching the completion of the book's manuscript, it is desirable to publish some additional new records of genera and species, as well as relevant nomenclatural acts, as a separate note from the forthcoming book.

To date, the fauna of spider wasps from Colombia has 150 known species, belonging to 38 genera and four subfamilies.

\section{Methods}

Examined specimens. The specimens are deposited in the Entomological collection at Instituto Alexander von Humboldt, Villa de Leiva, Colombia (IAvH-E), Instituto de Ciencias Naturales, Universidad Nacional de Colombia, Bogotá, Colombia (ICN), Entomological Collection of the Museo Javeriano de Historia Natural, Pontificia Universidad Javeriana, Bogotá, Colombia (MPUJ) and Museo Entomológico Universidad del Valle, Cali, Colombia (MUSENUV). Dicranoplius Haupt specimens from the Utah State University Entomology Collection, Logan, UT (EMUS) were examined.

\section{Results}

The following species and genera are reported for the first time in Colombia.

\section{Subfamily Pompilinae Aporinellus Banks}

Aporinellus aff. medianus Banks, 1917

Specimen data. Magdalena. $10^{\lambda}$, PNN Tayrona, Palangana $\left[11^{\circ} 20^{\prime} 0 " \mathrm{~N}, 74^{\circ} 2^{\prime} 0^{\prime \prime W}\right] ; 30$ m, malaise, 4-23 May 2001, R. Henríquez, M1765 (IAvH-E); $10^{\Uparrow}$, Neguanje, [11 ${ }^{\circ} 20^{\prime} 0^{\prime \prime N}$,

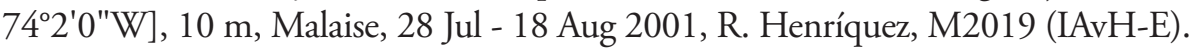


Comments. This is the first record of the genus for Colombia and northern South America. The known distribution of Aporinellus is worldwide, except Australia (Evans 1966). The studied specimens probably belong to an undescribed species that will be studied elsewhere.

\section{Austrochares Banks}

\section{Austrochares aff. mexicanus Dreisbach, 1966}

Specimen data. Magdalena. 1 , , PNN Tayrona, Neguanje, $\left[11^{\circ} 20^{\prime} \mathrm{N}, 74^{\circ} 2^{\prime} \mathrm{W}\right] ; 10 \mathrm{~m}$, malaise, 20 Apr-4 May 2001, R. Henríquez, (IAvH-E), 10̄, 4-23 May 2001, R. Henríquez, (IAvH-E).

Comments. This is the first record of the genus for Colombia and northern South America. Austrochares was previously known from Mexico to Argentina, including Brazil, Chile, and Peru (Evans 1969). The studied specimen keys out to A. mexicanus in Evans's (1969) key, but it probably belongs to an undescribed species that will be further studied elsewhere.

\section{Dicranopilus Haupt}

\section{Dicranopilus aff. areatus (Taschenberg, 1869)}

Specimen data. Bolívar. $2 \widehat{\gamma}$, Santuario de Fauna y Flora Los Colorados, Alto el Mirador, 6-24 Oct 2001, E. Deulufeut (IAvH-E). Magdalena. 8 $0^{\lambda}, 1$, PNN Tayrona, Neguanje,

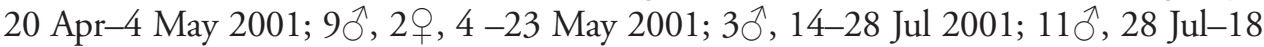
Aug 2001; 12 ${ }^{\lambda}, 17-27$ Sept 2001, R. Henriquez (EMUS, IAvH-E).

Comments. This is the first record of the genus for Colombia. Dicranoplius is restricted to the Neotropics, to both temperate and tropical South America. It was previously known from Trinidad south to Argentina (Evans 1969). The studied specimens key out as D. areatus in Evans's (1969) key, but they belong to an undescribed species, which will be described elsewhere.

\section{Euplaniceps Haupt}

\section{Euplaniceps notabilis (Smith, 1860), comb. n.}

Aporus (Aporus) notabilis notabilis (Smith, 1860), Mem. Am. Entomol. 20: 52.

Planiceps notabilis Smith, 1860, Jour. Ent., 1:80 [Type: female, Mexico] - Cresson, 1867, Trans. Amer. Ent. Soc., 1: 137.

Pompilus (Planiceps) notabilis Cameron, 1893, Biol. Centr.-Amer., Hymen. II, p. 186. 
Pompilus flavomarginatus Cameron, 1893, ibid, p. 191 [Type: female, Mexico: Yucatan. BMNH no. 19,703] Syn. by Evans 1966.

Odontaporus notabilis Bradley, 1944, Trans. Amer. Ent. Soc., 70: 114-115.

Specimen data. See Rodriguez et al. (2015), Appendix S1.

Comments. This is the first record of this species for Colombia. Euplaniceps notabilis was previously recorded from Mexico to Costa Rica (Evans 1966). The new combination is proposed based on molecular phylogenetic analyses (Rodriguez et al. 2015), which included A. notabilis (labeled "Euplaniceps sp.", voucher PO484) in the Euplaniceps clade, sister to the Antillean Drepanaporus. This species had previously been included in the genus Odontaporus by Bradley (1944) based on the presence of a tooth in the margin of the inferior mandible and bare eyes. Bradley (1944) did not mention the presence of this tooth in many Euplaniceps species (see Colomo de Correa 1998). Evans (1966) included this species in Aporus based mainly on the second submarginal cell receiving only one recurrent vein. This character is very variable even within Euplaniceps species (JR pers. obs.), where the second submarginal cell can receive one or two recurrent veins, with the second recurrent vein sometimes being interstitial with the second intercubital vein. Moreover, females of $A$. notabilis do not have a v-shaped spatium frontale as all other Aporus, but a flattened area between the antennal alveoli on the same plane as the clypeus which is found in many Euplaniceps species (see Colomo de Correa 1998). Finally, the male genitalia have parameres with parallel-side edges and truncated apex, which is a diagnostic character of Euplaniceps males. The two subspecies, A. n. notabilis and A. n. pulchritarsis, are herein included in Euplaniceps.

\section{Evagetes Lepeletier}

\section{Evagetes peruana (Banks, 1947)}

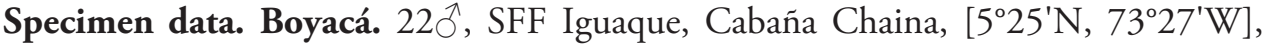
2,600 m, malaise, 9-26 Sept 2002, A. Roberto (IAvH-E).

Comments. This is the first record of this species for Colombia and east of the Andes. Evagetes is most diverse in the Holarctic region, having South American species occurring west of the Andes (Argentina, Chile and Peru) (Evans 1966; Fernández 2000). This species was previously known from Trujillo, Peru (Banks 1947).

\section{Priochilus Banks}

Priochilus formosum hondurense Dreisbach, 1950

Specimen data. Vichada. 1q, Centro Gaviotas, 170 m, 17 Oct 1989, F. Fernández leg. (ICN).

Comments. Fernández (2000) cited the occurrence of $P$. formosum hondurense Dreisbrach, 1950 in Colombia (Orinoco region), without providing specimen data 
and/or specimen voucher. We add a female specimen to this species' range. Priochilus formosum hondurense is known from females only and had been known from Honduras to Costa Rica (Evans 1966).

\section{Priochilus imperius Banks, 1944}

Specimen data. Meta. 1 , RNN La Macarena, Caño La Curía, 580 m., 25 Dec 1986, F. Fernández leg. (ICN).

Comments. Fernández (2000) reported the species from Bolivia, Brazil, Ecuador, Colombia (Meta) and in Peru (apud Evans 1966). Additionally, the Catalogue of Life (www.catalogueoflife.org) has added Chile to P. imperius list of occurrences. Specimen data and/or specimen voucher are not provided by Fernández (2000), making record questionable. Here we record a female specimen from Colombia. Priochilus imperius was described based on specimens from Bolivia, British Guiana, Ecuador, Peru, and Surinam (Banks 1944).

\section{Subfamily Pepsinae}

\section{Aimatocare Roig-Alsina}

Note. Roig-Alsina (1989) established the genus Aimatocare for the Chirodamus argentinicus species-group, as delimited by Evans (1968), but did not propose new combinations for the newly established genus. Herein, we formalize the following nomenclatural acts: Aimatocare argentinica (Banks), comb. n.; Aimatocare imitator (Evans), comb. n.; Aimatocare longula (Banks, 1946), comb. n.; Aimatocare impensa (Evans), comb. n.; and Aimatocare vitrea (Fox), comb. $\mathbf{n}$.

\section{Aimatocare longula (Banks, 1946)}

Specimen data. Cauca. 1 , , Morales, El Pomarroso, Finca El Recuerdo, [2 $48^{\prime} 34.5^{\prime \prime N}$, 76³7'15.8"W], 1,600 m, by hand, 12 Sept 2013, D. Caraball (MUSENUV).

Comments. This is the first record of this species for Colombia. It was previously known from Bolivia, Brazil and Peru (Fernández 2000).

\section{Chirodamus Haliday}

Chirodamus paramicola Roig-Alsina, 1984

Specimen data. Cundinamarca. 19 , PNN Chingaza, 3,400 m, hand collection, Nov 1988, G.D. Amat (MPUJ). 
Comments. Roig-Alsina (1984) recognized five species mostly from southern South America, with one species, C. paramicola, in Venezuela and Colombia. The holotype and paratypes are from the Venezuelan Andes, and the single specimen from Colombia was collected in Nariño (southwestern Colombia) and deposited in London without further study. We found a new specimen from Chingaza Park, which slightly differs from the type series by having different fore leg coloration. The Colombian specimen studied here comprises a possible geographical and morphological bridge between the Merida (Venezuela) and Narińo specimens.

\section{Dipogon Fox}

\section{Dipogon ariel Banks, 1946}

Specimen data. Boyacá. 1 , SFF Iguaque, Cabaña Chaina, [52 $25^{\prime} 0 " \mathrm{~N}, 73^{\circ} 7^{\prime} 0^{\prime \prime W}$, 2,600m, malaise, 10 Jun 2001, 28 Jun 2001, P. Reina (IAvH-E).

Comments. This is the first record of this species for Colombia. Dipogon ariel was previously known from Ecuador (Banks 1946).

\section{Acknowledgements}

We thank Claudia Medina from IAvH-E for her hospitality during JR's visit to Villa de Leyva, Colombia; Dimitri Forero (MPUJ) for the loan of Chirodamus; and Tiago $\mathrm{H}$. Auko and an anonymous reviewer for valuable contributions on the manuscript. CW thanks to FAPES (Fundação de Âmparo à Pesquisa e Inovação do Espírito Santo)/ CAPES for postdoctoral fellowship, grant \#71026436 and VC-H thanks to PEC-PG/ CAPES for doctoral fellowship, grant \#8954/14-3.

\section{References}

Banks N (1944) The Psammocharidae (Hymenoptera) taken at Kartabo and other localities in British Guiana. Zoologica: New York Zoological Society 29: 97-112.

Banks N (1946) Studies of South American Psammocharidae. Part I. Bulletin of the Museum of Comparative Zoology 96(4): 311-525.

Banks N (1947) Studies of South American Psammocharidae Part II. Bulletin of the Museum of Comparative Zoology 99: 371-486.

Bradley JC (1944) A preliminary revision of the Pompilinae (exclusive of the tribe Pompilini) of the Americas (Hymenoptera: Pompilidae). Transactions of the American Entomological Society 70: 23-157.

Castro-Huertas V, Pitts JP, Rodriguez J, Waichert C, Fernández F (2014) New records of spider wasps (Hymenoptera, Pompilidae) from Colombia. ZooKeys 443: 35-44. https:// doi.org/10.3897/zookeys.443.8348 
Colomo de Correa MV (1998) Contribución al conocimiento de los Pompilinae de Argentina (Hymenoptera: Pompilidae). V. El género Euplaniceps Haupt. Acta Zoologica Lilloana 44: $143-165$.

Evans HE (1966) A revision of the Mexican and Central American spider wasps of the subfamily Pompilinae (Hymenoptera: Pompilidae). Memoirs of the American Entomological Society 20: 1-442.

Evans HE (1969) Studies on Neotropical Pompilidae (Hymenoptera) V. Austrochares Banks. Psyche 76: 18-28. https://doi.org/10.1155/1969/50293

Fernández F (2000) Avispas Cazadoras de Arañas (Hymenoptera: Pompilidae) de la Región Neotropical. Biota Colombiana 1: 3-24.

Hanson PE, Wasbauer MS (2006) Familia Pompilidae. In: Hanson PE, Gauld ID (Eds) Hymenoptera de la Región Neotropical. Memoirs of the American Entomological Institute 77, 994 pp.

Rodriguez J, von Dohlen CD, Pitts JP (2010) The genus Psorthaspis (Hymenoptera: Pompilidae) in Colombia. Caldasia 32: 435-441.

Rodriguez J, von Dohlen CD, Pitts JP (2015) Historical biogeography of the recently diverged widespread spider wasp tribe Aporini (Hymenoptera: Pompilidae). Journal of Biogeography 42: 495-506. https://doi.org/10.1111/jbi.12430

Roig-Alsina A (1984) Contribución al conocimiento de los Pepsinae sudamericanos. El género Chirodamus Haliday (Hymenoptera, Pompilidae). Physis Sección C 42: 109-120.

Roig-Alsina A (1989) La posición sistemática de los grupos hasta ahora incluidos en Chirodamus Haliday sensu lato y revisión de Pompilocalus gen. nov. (Hymenoptera: Pompilidae). Revista de la Sociedad Entomológica Argentina 47(1-4): 3-73.

Waichert C, Rodriguez J, von Dohlen CD, Pitts JP (2012) Spider wasps (Hymenoptera: Pompilidae) of the Dominican Republic. Zootaxa 3353: 1-47.

Waichert C, von Dohlen CD, Pitts JP (2015) Resurrection, revision and molecular phylogenetics of Eragenia Banks with implications for Ageniellini systematics (Hymenoptera: Pompilidae). Systematic Entomology 40: 291-321. https://doi.org/10.1111/syen.12101 